\title{
La enseñanza de la literatura a estudiantes extranjeros
}

\author{
Mtra. Sara Martínez*
}

In memoriam: Héctor Valdés.

"La literatura nació el día que un chico llegó gritando: ¡El lobo, el lobo!, sin que lo persiguiera ningún lobo".

(Vladimir Nabokob, Curso de Literatura Europea).

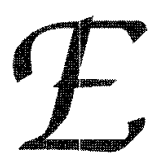

$\mathrm{n}$ esta intervención quiero resaltar la importancia de la literatura como parte de la enseñanza de una lengua. Creo que todos los presentes coincidimos en la preocupación legítima por los índices de falta de interés de los alumnos por la literatura. Esto me lleva a pensar que es necesario, en todos los niveles del diseño didáctico, plantear el problema en general para avanzar una propuesta en el caso de los estudiantes extranjeros.

La enseñanza de la lengua y la enseñanza de la literatura deberían ir de la mano $-y$ digo deberían porque no siempre es así-, pues tengo la sensación de que la literatura es cada vez menos socorrida en la enseñanza del español. El español es una materia obligatoria en el nivel básico (primaria y secundaria) y en el nivel medio (preparatoria, bachilleres, bachillerato tecnológico y educación profesional técnica). En mayor o menor medida, los programas respectivos incluyen contenidos de literatura; la mayoría de los docentes de la materia incurren, por falta de preparación o de perspectiva, en el error de excluir a cualquiera de las dos. Es decir, si al maestro le gusta la lengua, multiplica por cero a la literatura $y$, en caso contrario, si es un lector apasionado, rara vez tiene un formato completo y suele eliminar de su discurso didáctico a la lengua, pues no la conoce con suficiencia. Soy una convencida e incluso una militante del enfoque comunicativo para la enseñanza de la lengua materna $y$ de las lenguas extranjeras, más el requisito que dicho método impone a los diseñadores de materiales, a saber: el uso de "materiales auténticos", parece querer discriminar a los textos literarios de los cursos de lengua, como si tales no fueran auténticos. Sobra y no sobra aclarar que la teoría del método comunicativo obviamente no los excluye, aunque tampoco son su objetivo y esta particularidad libera a los responsables del desarrollo de cursos de un compromiso con la enseñanza de la literatura.

Recientemente tuve la experiencia de contratar a una joven profesora de español, muy recomendada por cierto, para el nivel de secundaria, a quien también le pregunté si tenía disponibilidad de horario para enseñar literatura en bachillerato. Su respuesta fue alarmantemente honesta: me encanta enseñar español, pero no sé nada de literatura y la literatura me "choca" (con lo que me hizo temer que tampoco era muy ducha en analizar su propia lengua, pues poco faltó para que dijera "schokea"). ¿Acaso los profesionales de la lengua no son profesionales de la literatura? ¿Acaso no lo son Roland Barthes, Georges Steiner, Antonio Alatorre, Harald Weinrich o Umberto Eco, por decir algunos ejemplos egregios, en los que no podemos imaginar su obra sin el dominio prácticamente total de ambas? Mis preguntas no son retóricas, tampoco son irónicas; no son aseveraciones, son tal vez el fruto de mi perplejidad.

*Directora del CEPE 1985-1989 
Para Roland Barthes:

Hay un estatuto particular de la literatura que depende de lo siguiente: que está hecha con el lenguaje, es decir, con una materia que ya es significante en el momento en que la literatura se apodera de ella: la literatura tiene que deslizarse en un sistema que no le pertenece pero que a pesar de todo funciona con los mismos fines que ella: comunicar'.

De esta manera, eso que llamamos cultura conforma el sistema de vasos comunicantes de toda forma de comunicación, en el que la lengua y la literatura, presiden un paisaje similar al que solían coronar las torres gemelas de Nueva York. Es en parte nuestra preocupación que, por falta de consistencia en nuestros sistemas de seguridad o simple apatía colectiva, un buen día se desmoronen. Pero más allá de lo hiperbólico de mi alarma, vale recalcar algo evidente: realmente considero que ni el estudio ni la enseñanza de la lengua pueden prescindir de la literatura, que es sin duda prueba de la madurez de una lengua, pues hay que recordar con Georges Steiner que el lenguaje se venga de quienes lo mutilan ${ }^{2}$. En los años sesenta (1966) Bertil Malmberg afirmaba que las lenguas occidentales

[...] alcanzaron... en el umbral de la edad moderna, una solidez y flexibilidad suficientes, así como también una tradición literaria considerable, de manera que estaban capacitadas incluso para funcionar como lenguas literarias ${ }^{3}$.

La discusión de las últimas décadas se da entre la postura que pretende llegar a la excelencia en el conocimiento de una lengua, a través de la profundización en la cultura-meta, o la que aspira meramente a la eficiencia de una comunicación en situaciones prácticas.
Si nos adhiriéramos a la segunda postura ¿tendríamos acaso que prescindir de los textos literarios? Huberto Batis, maestro de muchos de nosotros, nos hacía leer completo el volumen de Teoría Literaria de Wellek y Warren y sentenciaba que debíamos consultarlo toda la vida. Hace poco, me encontré con una insinuación del enfoque comunicativo, escrita cuando ni siquiera se hablaba de él:

[...] el lenguaje literario dista mucho de ser meramente designativo. Tiene su lado expresivo; conlleva el tono y la actitud de quien habla o del que escribe; $y$ no declara o expresa simplemente lo que dice, sino que quiere influir en la actitud del lector, persuadirle $y$, en última instancia, hacerle cambiar...

También, al referirse al lenguaje cotidiano (el lenguaje ordinario, como lo llamaron Austin y Searle, en cuya filosofía se basa la Pragmática Lingüística que dio origen al enfoque comunicativo), Wellek y Warren afirman:

Sin duda, el lenguaje cotidiano quiere las más de las veces conseguir resultados, influir en actos y actitudes. Pero sería erróneo circunscribirlo simplemente a la comunicación. El parloteo de un niño durante horas enteras sin que nadie le escuche y la cháchara mundana de los adultos, casi desprovista de sentido, ponen de manifiesto que hay muchos usos del lenguaje que, estrictamente, o al menos primariamente, no son comunicativos. ${ }^{5}$

La enseñanza de una lengua, sea materna o sea extranjera, practicada con un enfoque comunicativo, atiende en la selección de sus textos aquellos que encierran una intención que puede modificar la actitud de los receptores. Por ello, los textos contemporáneos al momento de la enseñanza son los más socorridos, y esos textos

\footnotetext{
${ }^{1}$ Barthes, Roland, Ensayos criticos, Seix Barral, Barcelona, 1967, p. 314.

${ }^{2}$ Steiner, Georges, Lenguaje y silencio, Gedisa, México, 1990, p. 57.

${ }^{3}$ Malmerge, Bertil, La lengua y el hombre, Istmo, Madrid, 1974, p. 126.

${ }^{4}$ René Wellek y Austin Waren; Teoría Literaria, Prólogo: Dámaso Alonso, $4^{\circ}$ Ed. Madrid, Gredos, 1966, p. 28

${ }^{5}$ ibídem, p. 29
} 
los encontramos en las conversaciones cotidianas, cuando de comprensión auditiva se trata, $y$ en los periódicos, revistas, historietas cómicas y libros de divulgación, cuando de comprensión de lectura hablamos. Aquí nos acercamos al tema que me ocupa: la comprensión de la lectura, una de las cuatro habilidades que requiere el individuo para ser competente, comunicativamente hablando. Considero que un estudiante de lengua, que está en el proceso de adquirir esa destreza, debe entrenarse en la lectura de textos literarios para realmente profundizar en su conocimiento de la lengua ya que los recursos del lenguaje se explotan en la literatura mucho más deliberada y sistemáticamente [nota: los subrayados son de la autora], como afirman Wellek y Waren. Por otro lado, la lectura de textos literarios ayuda a comprender de manera más conceptual a la cultura meta, puesto que en muchas obras se nos manifiesta una "personalidad" mucho más coherente y totalizadora que la de las personas tal como las vemos en situaciones corrientes. Con todo esto quiero subrayar la atención sobre el hecho particular de que quizá el interés de los alumnos por los cursos de literatura tenga una relación proporcionalmente simétrica con la falta de atención, en el momento de elaborar los programas y temarios, respecto a los gustos, aficiones, intereses y necesidades que conforman una didáctica basada en la necesidad del aprendizaje significativo. Esto me recuerda una hermosa cita de Alberto Manuel, en su bellísima historia de la vida cotidiana de los lectores (Una historia de la lectura):

Decir que leemos -el mundo, un libro, el cuerpo- no basta. La metáfora de la lectura requiere a su vez otra metáfora, exige una explicación mediante imágenes que quedan fuera de la biblioteca del lector pero dentro de su cuerpo, de manera que la función de leer se asocia con nuestras otras funciones corporales básicas.
Leer - como hemos visto- sirve como vehículo metafórico, pero para entenderlo hay que reconocerlo también mediante metáforas. De la misma manera que los escritores hablan de que un libro es un refrito, de salpimentar una escena, de hincarle el diente a un discurso, nosotros, los lectores, hablamos de saborear un libro, de alimentarnos con él, de devorarlo en una sentada, de regurgitar un texto, de rumiar un pasaje, de sentirle el gusto a la poesía, de mantenernos con una dieta de novelas policíacas. ${ }^{6}$

Pero, ¿qué es la literatura y cómo incide en la mejor manera de aprender una lengua?

Según Juri Lotman', cualquier texto que, dentro de los límites de una cultura dada, sea capaz de cumplir una función estética ${ }^{8}$ es digno de considerarse una muestra de literatura. El mensaje verbal adquiere, como afirma Helena Beristáin, el rango de obras de arte cuando se inserta dentro de las específicas condiciones contextuales dadas por las convenciones literarias y culturales institucionalizadas en el momento de su producción, en la sociedad que acredita su calidad literaria. ${ }^{9}$

Creo que muchos de ustedes estarán de acuerdo conmigo cuando sostengo que la experiencia estética supera a cualquier tipo de experiencia social. Leer literatura es un acto superior que, al practicarlo diariamente, se convierte en un rito sagrado. Si el lenguaje nos diferencia de los demás animales o, como diría Malmberg nos "hominiza"

(Un ser incapaz de captar $y$ experimentar conceptos no puede crear una lengua. Lengua y formación de ideas son, en el fondo, una sola cosa, y constituyen expresión de idéntica capacidad; la lengua y el pensamiento son, en sentido estricto, lo mismo. La aparición de la capacidad lingüistica resulta igual a la hominización).

\footnotetext{
${ }^{6}$ Manuel, Alberto, Una historia de la lectura, Norma, Santa Fe de Bogotá, 1999.

7 "The Content and Structure of the Concept o Literature" en PTL, Ámsterdam, 1976.

${ }^{r}$ Helena Beristáin, Diccionario de Retórica y Poética, octava edición, México, Porrúa, p. 305.

${ }^{9}$ fdem.

${ }^{10}$ fdem.
} 


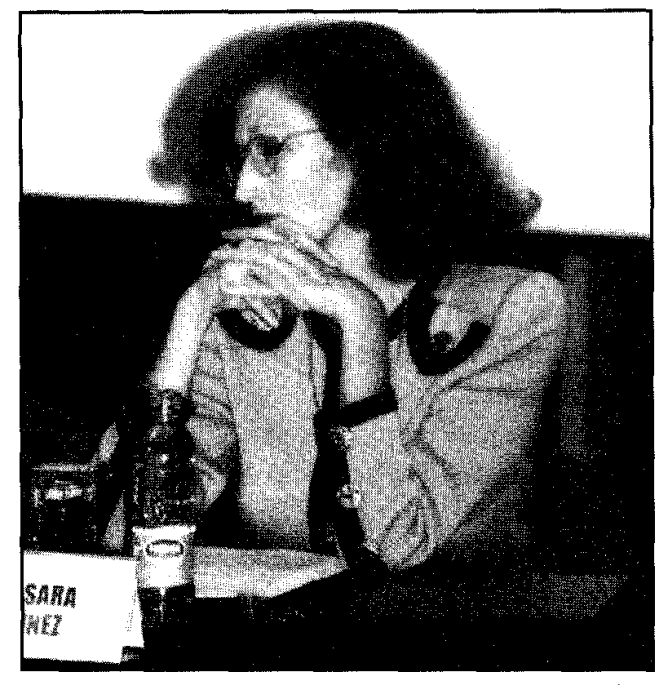

Mtra. Sara Martínez

La lectura nos distingue de los demás humanos $y$ la lectura de obras literarias nos permite observar al mundo $y$ a nuestros congéneres con una óptica más diáfana. Helena Beristáin afirma que en la literatura:

el receptor halla, filtrada a través de la impresión estética que produce el texto, una profunda experiencia del mundo que se le comunica al asumir la obra ciertos modelos ideológicos que, naturalmente, son históricos. ${ }^{10}$

Entonces ¿qué instrumento es más idóneo que la literatura para convertir al aprendizaje de una lengua en un aprendizaje no sólo significativo, sino superior?

¿Cómo enseñar la literatura de manera que el estudiante de lengua compruebe que se trata de un instrumento útil para sus fines?

Si para muchos estudiantes, lo que importa es que la literatura les sea útil. ¿Cómo, entonces, lograr que compruebe que ésta le es útil para sus fines?
Malmberg afirma:

Quien haya llegado alguna vez a la evidencia de que la educación y el adiestramiento en el uso correcto de la lengua —es decir, en la capacidad de expresar correctamente por escrito $y$ oralmente un contenido y de captar exactamente el sentido básico de una palabra, sus matices y valores estilísticos- trae consigo simultáneamente un acrecentamiento en la capacidad de pensar $y$ comprender con claridad lo que se dice o escribe, estará inclinado a ver de otra manera la cuestión. Sin los análisis, abstracciones y agrupaciones que nos proporciona la lengua, la existencia sería para nosotros un hecho amorfo, un continuum vago desprovisto de contornos."

Y yo agregaría que el entrenamiento que da la lectura de textos literarios enriquece notablemente la capacidad "de captar exactamente el sentido básico de una palabra, sus matices y valores estilísticos" y con ello la posibilidad de analizar la realidad, de abstraer, en una palabra: de pensar.

¿Cómo lograr que los alumnos lo entiendan y acepten la necesidad de aprender literatura?

\footnotetext{
1dem.

${ }^{11}$ Bertil Malmberg; La Lengua y el hombre. Introducción a los problemas generales de la Lingüística, -Madrid. ISTMO. p.124-5.
} 
Diseñando materiales, cuyos ejercicios provoquen la sorpresa de la comprensión. Para ello, los docentes tenemos que ser muy creativos y proponer textos atractivos. De esto hablaremos más adelante. La realidad es que muchas veces erramos en la selección de los textos, al dejarnos llevar por lo que nosotros consideramos imprescindible, que no siempre resulta ser lo comprensible para el grado de conocimiento de la lengua de nuestros alumnos, sean mexicanos o sean extranjeros. Un ejercicio de humildad $y$ de realismo, sin descuidar la calidad de los textos seleccionados es imperativo en este ejercicio.

¿Qué materiales podrían ayudar a la estudiante a necesitar de la literatura durante su proceso de aprendizaje de la lengua?

Integrar textos literarios al diseño de material didáctico de la lengua es fácil de proponer, pero difícil de realizar. Es preciso hacer una selección de acuerdo al grado de dificultad semántica $y$ sintáctica. Por otra parte, el contenido y el estilo de los textos tienen que coincidir con el interés de los posibles usuarios de dichos materiales.

A lo anterior hay que añadir el conocimiento teórico y empírico del uso de las estrategias de lectura, aplicables a los textos literarios: la identificación de palabras clave, la pertinencia o impertinencia de la discriminación de ideas principales de las ideas secundarias, la técnica de la predicción, la inferencia de significados, la referencia, la coherencia, la deducción y otras.

Los profesores que se dedican al diseño de materiales no sólo son especialistas en lengua y poseen una amplia, larga y cotidiana experiencia ante grupo, sino que han de tener un conocimiento de nuestra literatura tal que les permite echar mano del texto adecuado para las fases concretas del desarrollo de un curso. Dicho sea de paso, y si no se había dado cuenta, que lo dudo, estoy dibujando el perfil de mis colegas del Centro de Enseñanza para Extranjeros, quienes trabajan con responsabilidad, inventiva y espíritu de equipo, me consta.
A lo largo de sus ocho décadas, la antigua Escuela de Verano y el actual Centro de Enseñanza para Extranjeros han producido materiales didácticos de enorme pertinencia y utilidad. Profesores dedicados y expertos, más profesoras que profesores, realizaron esfuerzos individuales de gran eficacia $y$ variedad. A mediados de los años ochenta, el ímpetu de actualización de mis colegas los llevó a trabajar en equipo y, en los años sucesivos, se fueron generando las series de Pido la palabra y iEstoy listo! Los autores de estos libros han sido los pioneros de la enseñanza del español como lengua extranjera, con el enfoque comunicativo y su éxito ha sido bien ganado. Sé que ahora el área de español se encuentra en una nueva fase de actualización, en la que seguramente se enriquecerán las perspectivas y se ampliará el horizonte cultural. En esta fase, necesariamente, habrá que dar el énfasis que reclama la literatura, integrándola definitivamente a los contenidos del programa de español para extranjeros de la Universidad Nacional Autónoma de México

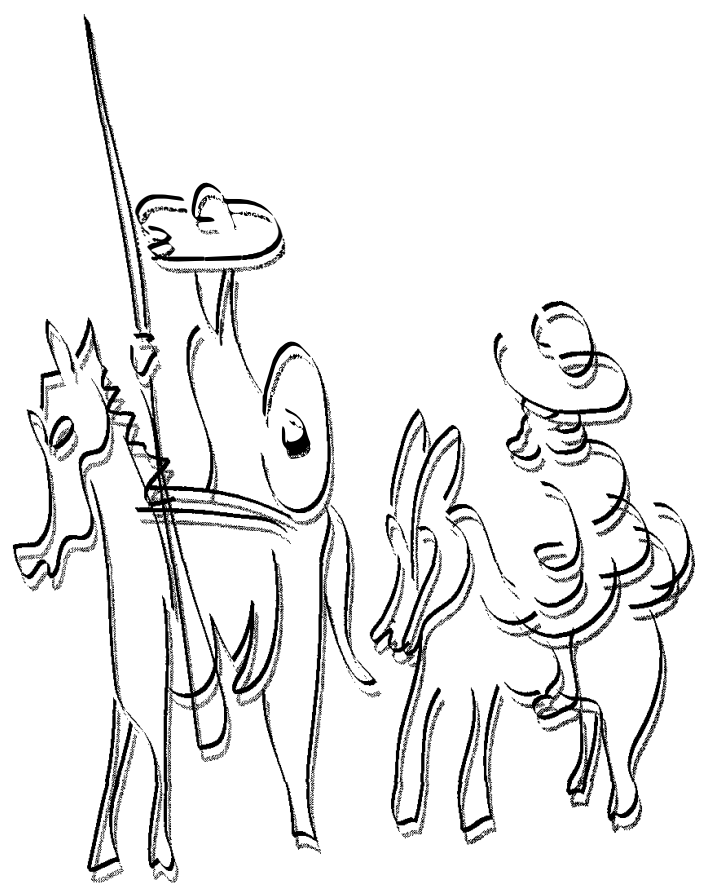

